Kong. Res. J. 3(1) : 56-58, 2016

ISSN 2349-2694

Kongunadu Arts and Science College, Coimbatore.

\title{
SURVEY ON THE NARROW ENDEMIC THREATENED PLANTS IN MADURAI DISTRICT OF TAMIL NADU, INDIA
}

\author{
Jayakumar M11. and S. Karuppusamy* \\ ${ }^{1}$ Department of Biology, PMT College, Usilampati. \\ ${ }^{2}$ Department of Botany, Centre for Botanical Research, The Madura College, Madurai. \\ *E.mail: ksamytaxonomy@gmail.com
}

\begin{abstract}
Medicinal plant survey was conducted and assessed the narrow endemic, endangered and threatened plants in Madurai district of Tamil Nadu during the year 2013-2014. There are 9 narrow endemic threatened plant species enumerated and further analysed their distribution with various threat categories both global and regional scale. Hygrophila madurensis is only one species were identified critically endangered and other species are not evaluated so for IUCN categories but they are distributed narrowly to Madurai and adjacent districts of Tamil Nadu. The data provide the information for diversity of threatened plant species to design the sustainable utilization and conservation measures.
\end{abstract}

Keywords: Endemic plants, threatened species, conservation.

\section{INTRODUCTION}

Among the plant diversity of India, endemic medicinal plants are an important source which have been used all over the world. It has been widely used by all sections of the population, and country is richly endowed with a wide variety of plants of medicinal value, which represents the great national resource (Myers et al., 2000). It is approximately estimated that at least 70 per cent of country's population relay on herbal medicines for primary health care. In India, different classical medicinal systems such as Ayurveda, Siddha and Unani are being practiced since time immemorial in the country and in addition to these, innumerable local folk medicinal traditions exist. In total about 8000 plant species are in medicinal use. It constitutes around 45 per cent of 17,500 known flowering plant species of India (Ravikumar and Ved, 2000). This rich medicinal wealth is mainly distributed in two hot spots diversity that is north eastern region and Western Ghats. The Western Ghats comprises of a hill range running about $1500 \mathrm{~km}$ long the western edge of Indian sub-continent. Although it covers a mere 5 per cent of the country's total land area in the country, it is believed to be more than 27 per cent of country's plant species remarkably high level of endemism ranging from 25 to 60 per cent of recorded species (Pascal, 1992). Narrow endemic plants are important components of the biodiversity of the Western Ghats. The high anthropogenic pressures and associated fragmentation of natural forests have resulted in loss of habitat and species. Several endemic plants species are also under constant threat due to over exploitation from natural habitats for its commercial values in the absence of cultivation. Biogeographically, the Western Ghats have long been isolated from the vast south-east Asian humid forest tract and thus protect a relict pocket of evolutionarily distinct biota. Geology, soil and climate also contribute to promote high biodiversity in these regions.

Peninsular India has a centre of flowering plant endemism, due to diversity of climate and vegetation (Ahmedullah and Nayar, 1987; Nayar, 1996). The Western Ghats of India is one of the 34 global biodiversity hotspots of the world (Myers et al., 2000) and over one-third of its angiosperms are endemic (Kaveriappa and Shetty, 2001). It is a chain of mountains of $1600 \mathrm{Km}$ in length running parallel to west cost of Peninsular India from the river Tapthi to Kanyakumari, the southern tip of peninsular India. Many of these endemics are threatened due to human impacts and figure in the threatened categories of the International Union for the Conservation of Nature (IUCN, 2015). Madurai is one of the small district in Tamil Nadu and has medium proportion of its landscape under tree cover (30\%). The reserve forests and protected areas are owned and managed by the forest department and they constitute about 18 per cent of geographical area. The study area of Madurai district is an attractive spot for taxonomist over past centuries, as possessed a part of rich plant diversity in both Western Ghats and Eastern Ghats. 


\section{MATERIALS AND METHODS}

The study area of Madurai district is lying between $9^{0} 58^{\prime} \mathrm{N}-78^{0} 10^{\prime} \mathrm{E}$ to $9^{0} 95^{\prime} \mathrm{N}-78^{0} 13^{\prime} \mathrm{E}$ with different forest vegetation types. It covers an area of $3,742 \mathrm{~km}^{2}$ with rich diversity of potential endemic plants which are many of them are medicinal. Frequent field visits conducted to the area for surveying medicinal plants and collecting the data if local medicinal uses of plants from the study area. The plant specimens were collected in nondestructive manner. The specimens were made into herbarium for identification with standard traditional method. The primary identification of plant specimens done with help of local and regional Floras (Gamble, 1915-1936; Henry et al., 1987; Matthew, 1983; Hooker, 1872-1897) and the conformity of identification compared with authentic herbarium deposited Botanical Survey of India, Southern Circle, Coimbatore. The list of medicinal species prepared and analysed the endemic, endangered and threatened plants with pertinent literature (Henry et al., 1979; Nayar, 1982 and 1996; Nayar and Sastry 1987 - 1990; Ramesh and Pascal,
1997; http//www.iucnredlist.org). The available narrow endemic medicinal plants enumerated from the study area for the preparation of conservation measured to ensure the survival of potential medicinal plants for posterity.

\section{RESULTS AND DISCUSSION}

In Madurai district composed of scrub forest, dry deciduous to moist deciduous teak forest and dispersed with semievergreen forests at Alagar hills. There are 9 plant species identified as narrow endemic plants which are distributed only in Madurai district and adjacent areas (Table 1). Out of 9 species, one species is critically endangered, 8 species are not assessed so far. Many of these species are highly exploited for trade purpose either medicinal or some other purposes that are Caralluma adscendens, C. sarkariae are largely extracted for both timber and medicinal value. Of these narrow endemic plants, 8 species are restricted to Madurai and surrounding areas, though these species are facing great problem for its survival due to high value utilization in Indian medicine.

Table 1. Narrow endemic threatened plants of Madurai district, Tamil Nadu.

\begin{tabular}{|c|c|c|c|}
\hline S.No. & Plant name & Family & $\begin{array}{l}\text { Distributional } \\
\text { range }\end{array}$ \\
\hline 1. & $\begin{array}{l}\text { Caralluma adscendens (Roxb.) R.Brown var. bicolor } \\
\text { V.S.Ramach.S.Joseph, H.A.John \& Sofiya }\end{array}$ & Apocynaceae & $\begin{array}{l}\text { Dindigul, } \\
\text { Coimbatore }\end{array}$ \\
\hline 2. & $\begin{array}{l}\text { Caralluma adscendens (Roxb.) R.Brown var. carinata } \\
\text { Gravely et Mayuranathan }\end{array}$ & Apocynaceae & Theni \\
\hline 3. & Caralluma sarkariae Lavranos et Frandsen & Apocynaceae & Dindigul \\
\hline 4. & Crotalaria digitata Hook. & Leguminosae & Dindigul \\
\hline 5. & Fimbristylis paupercula Boeckeler & Cyperaceae & $\begin{array}{l}\text { Dindigul, } \\
\text { Tirunelveli }\end{array}$ \\
\hline 6. & Fimbristylis rugosa Govind. & Cyperaceae & Dindigul, Theni \\
\hline 7. & $\begin{array}{l}\text { Fuirena pubescens (Poir.) Kunth var. pergamentaceae } \\
\text { C.E.C.Fisch }\end{array}$ & Cyperaceae & Virudhunagar \\
\hline 8. & Henckelia gambleana (C.E.C.Fisch.) A.Weber \& B.L.Burtt & Gesneriaceae & $\begin{array}{l}\text { Dindigul, } \\
\text { Coimbatore }\end{array}$ \\
\hline 9. & $\begin{array}{l}\text { Hygrophila madurensis (N.P. Balakr. \& Subr.) Karthik. \& } \\
\text { Moorthy }\end{array}$ & Acanthaceae & Pudukottai \\
\hline
\end{tabular}

This is the preliminary survey of the narrow endemic plant diversity in Madurai district of Tamil Nadu. It provides some base line data for sustainable utilization and conservation measures for potential national bioresources. Ecological amplitude is the ability of a growing medicinal plants species in habitat with environmental gradients. Several scientists have referred to this feature by various terms like niche width, habitat preferences or habitat versatility. Until now there are no exclusive studies on the population biology or ecological amplitude of narrow endemic threatened plants. Airi et al. (2000) have assessed the habitat ecology of Nardostachys jatamansi a critically endangered herbaceous plant species of western Himalaya. Varghese et al. (1999) have studied the ecological status of different tree species including some medicinal tree like Artocarpus hirsutus in Peppara Wildlife Sanctuary, Kerala. In Tamil Nadu, the studies need for the effect of distribution levels, forest types and association on the regeneration of important narrow endemic plant species. A few studies have 
reported for regeneration and distribution of narrow endemic trees like Palaquium ellipticum (Ganesh et al., 1996), Myristica malabarica (Mali et al., 2001) and Embelia ribes (Rajanna et al., 2001). More recently the Madura swampweed (Hygrophila madurensis) rediscovered after the type collection from Pudukottai district of Tamil Nadu (Raja et al., 2015).

In many cases, the declining habitats of native plants can no longer supply the expanding market for medicinal plant products. In the case of rare, endangered or over-exploited plants, cultivation is the only way to provide material without further endangering the survival of those species. The best means of conservation is to ensure that the populations of species of plants continue to grow and evolve in the wild in their natural habitats. The study gives basic knowledge about documentation of niches and amplitude of rare, threatened and endemic species in a regional scale. This documentation can help locate areas and habitats of high concentration of these species so that critical habitat/habitat sites would get priority for conservation.

\section{REFERENCES}

Ahmedullah, M. and M. P. Nayar, (1986). Endemic plants of the Indian region. Botanical Survey of India, Calcutta.

Airi, S., R.S. Rawal, V. Djar and A.M. Purohit, (2000). Assessment of availability and habitat presence of Jatamasi acritically endangered medicinal plant of West Himalaya. Curr. Sci. 79:1467-1470.

Gamble, J.S., (1915-1936). Flora of the Presidency of Madras. Adlard \& Sons Ltd., London.

Ganesh, T., M. Ganesan, Soubadra Devy, P. Davidar and K.A. Bawa, (1996). Assessment of plant biodiversity at a mid-elevation evergreen forest of Kalakad - Mundanthurai Tiber Reserve, Western Ghats. Curr. Sci. 71: 379-392.

Henry, A.N., G.R. Kumari and V. Chithra, (1987). Flora of Tamil Nadu, India, Ser.1, Vol. 2. Botanical Survey of India, Coimbatore.

Henry, A.N., K. Vivekananthan and N.C. Nair, (1979). Rare and threatened flowering plants of south India. J. Bombay Nat. Hist. Soc. 75: 684-697.

Hooker, J.D. (1872-1897). The Flora of British India, Vol. I-VII. Reeve \& Co.,London.

IUCN, (2011). IUCN Red List of threatened species. http://www.iucnredlist.org

Kaveriappa, K.M. and B.V. Shetty, (2001). Biodiversity of the Western Ghats with special reference to conservation of plant Diversity at Kaiga. Int. J. Nuclear Pow.15 (1-4): 40-42.
Mali, S., P.K. Ved and T.S. Srinivasmurthy, (2001). An approach to conservation of threatened plant species through species recovery. Tropical ecosystems: Structure, Diversity and Human welfare, proceedings of the international conference on tropical ecosystems. Eds. K.N. Ganeshaiah R. Umashanker and K.S. Bawa. Published by Oxford IBH, New Delhi, pp.670-673.

Matthew, K.M., (1983). Flora of Tamil Nadu Carnatic, Vol. 2. Part 1\&11. Rapinat Herbarium, Tiruchirapally, Tamil Nadu.

Myers, N., R.A., Mittermeier, G.A.B. da Fonseca and J. Kent, (2000). Biodiversity hotspots for conservation priorities. Nature 403: 853-857.

Nayar, M.P. and A.R.K. Sastry, (1987, 1988, 1990). Red Data Book of Indian Plants,Vols. I - III. Botanical Survey of India, Calcutta.

Nayar, M.P. and R.K. Sastry, (1988). Red data book of Indian plants. Botanical Surve of India. pp. 39-61, 49-72.

Nayar, M.P., (1982). Endemic flora of Peninsular India and its significance. Bull. Bot. Surv. India 19(1-4): 145-155.

Nayar, M.P., (1996). Hotsspots of endemic plants of India, Nepal and Bhutan. Tropical Botanical Garden and Research Institute, Trivandrum.

Nihara, R.G., A.E.D. Daniels, I.A.U.N. Gunatilleke, C.V.S. Gunatilleke, P.V. Karunakaran, K.G. Nayak, S. Prasad, P. Puyravaud, B.R. Ramesh, K.A. Subramanian and G. Vasanthy, (2007). A brief overview of the Western Ghats - Sri Lanka biodiversity hotspot. Curr. Sci. 93(11): 15671572.

Raja, P., S. Soosairaj, N. Dhatchanamoorthy and A. Kala, (2015). A new distribution record for the critically endangered Madura swamp weed Hygrophila madurensis (N.P. Balak. \& Subr.) Karthik. \& Moorthy (Acanthaceae). J. Threat. Taxa 7(9): 7581-7583.

Rajanna, M.D., N. Pradeep, K.P. Srikanth, Chandrika and B. Gowda, (2001). Distribution and propagation performance of Embelia ribes Burm an endangered endemic medicinal plant species in Western Ghats of Karnataka. My Forest, 37: 335342.

Ramesh, B.R. and J.P. Pascal, (1997). Atlas of endamics of the Western Ghats (India): Distribution of the tree species in evergreen and semi evergreen forests. Inst. Francasse De Pondichery, pp. 282.

Ravikumar, K. and D.K. Ved, (2000). Illustrated field guide-100 Red listed medicinal plants of conservation concern in Southern India, Pub: Foundation for revitalisation of local health traditions, Bangalore, pp. 15-330. 